\title{
Secondary succession after perturbations in a shrubland community
}

\author{
Leonor Calvo *, Reyes Tárrega, Estanislao de Luis \\ Area de Ecología, Facultad de Biología, Universidad de León, 24071 León, Spain
}

Received 23 January 2002; accepted 19 July 2002

\begin{abstract}
Shrubland responses to experimental burning, cutting and ploughing treatments were studied over 15 years in two shrubland communities dominated by Erica australis. The treatments represent the most frequent forms of anthropogenic disturbances experienced by these communities throughout their history. The response to burning and cutting treatments is similar, and the succession process is characterised as autosuccession. The highest values for herbaceous annuals and perennials were observed in the third and fourth years. Generally, herbaceous species remain present throughout the study period, while woody taxa ones increase their cover values over time. The quantity of herbaceous species present is in inverse proportion to the quantity of woody taxa. The woody species that appear immediately after treatments are sprouting species, namely Erica australis and Arctostaphylos uva-ursi. The response to ploughing is slower, reflecting the recovery mechanism (seedlings). However, after 15 years, there are no significant differences in regeneration between treatments. The first stages of this post-ploughing succession are dominated by annual species until the fourth or fifth years, after which woody species begin to dominate and herbaceous taxa decrease considerably. Woody species with high germination values are Halimium alyssoides and Halimium umbellatum. These shrubland communities have a very high resilience to such perturbations and start regenerating rapidly, reaching the original state in about 9 years. The appearance of the climax arboreal species of the area, Quercus pyrenaica, when it comes from germination, occurs 15 years after the perturbations. (C) 2002 Éditions scientifiques et médicales Elsevier SAS. All rights reserved.
\end{abstract}

Keywords: Mediterranean ecosystems; Human perturbations; Burning; Cutting; Ploughing; Regeneration; Autosuccession

\section{Introduction}

The present state of vegetation depends partly on human factors, which have influenced the plant communities in the past, and which still continue to do so (Godron et al., 1981). The Mediterranean ecosystems of Europe have been subject to a long history of human use (Grove, 1996; Margaris et al., 1996). For hundreds and even thousands of years, they have suffered from intense anthropogenic perturbations. Among the most important forms of disturbance are forest fires (Trabaud, 1980, 1991; Casal, 1985, 1987; Luis et al., 1989a,b; Clement and Touffet, 1990; Calvo, 1993; LeHouerou, 1993; Calvo et al., 1998a; Naveh, 1999) and cutting (Casal, 1985; Cody, 1986). These long-term disturbances have led to the extensive destruction of treedominated vegetation formations in large areas of the Mediterranean basin (Naveh and Dann, 1974; Barbero et al., 1990) and transformed it into shrublands, creating a mosaic

\footnotetext{
* Corresponding author.

E-mail address: deglcg@unileon.es (L. Calvo).
}

of ecosystems indicative of degradation (Di Castri, 1981). In the northwest of the Iberian Peninsula (León province), these types of shrubland communities cover $33 \%$ of the total area, according to the Ministry of Agriculture (Ministerio de Agricultura, 1984). Erica australis is the most characteristic shrub in these shrubland communities (Luis et al., 1989a,b).

These shrub communities have been considered marginal lands from the viewpoint of territorial development as they have low productivity. They have been subjected to human interference since ancient times. The basic management has been by grazing, as used to occur in other heathlands in the north and west of Europe (Webb, 1998). One of the most frequent forms of disturbance is the use of fire to create open areas for grazing. The second most common type of perturbation is cutting, the products of which have different purposes: as domestic fuel and fertilisers (Casal, 1985; Calvo et al., 1992). Thirdly, the shrublands have been ploughed up in order to create arable land, a common practice in the province of León during the 1960s. As time passed and agrarian policy changed, these farming areas were abandoned in the 1970s, and this started a succession 
process towards heath communities. These shrublands are characterised by rapid post-fire recovery of vegetation (Keeley, 1986; Westman and O'Leary, 1986; Clemente et al., 1996). After burning and cutting and when cultivated lands have been abandoned, the community begins a secondary succession process, which has been identified as autosuccession in these formations (Calvo, 1993; Calvo et al., 1998a,b).

Vegetation recovery after perturbations is started by seedling recruitment from a dormant seed bank or by sprouting from below-ground vegetative buds (Keeley, 1986; Trabaud, 1987; Ojeda et al., 1996; Lloret and Vilá, 1997). Life-form and other life historical features interact with regeneration strategies and with physical and chemical components of the environment, creating a complex framework within which regeneration takes place (Clemente et al., 1996).

The aim of this study is to define the changes in vegetation over a period of 15 years after perturbations in shrubland communities dominated by Erica australis. Variations in plant community structure and composition were recorded throughout the regeneration process. An attempt was also made to define the limits of successional stages in terms of these variations.

\section{Materials and methods}

Two study areas close to the highlands of León province were selected. Zone A was situated at latitude $5^{\circ} 08^{\prime} \mathrm{N}$, longitude $42^{\circ} 41^{\prime} \mathrm{W}$, approximate altitude $1000 \mathrm{~m}$, on a flat summit. The second, zone B, was $5 \mathrm{~km}$ south of A at latitude $5^{\circ} 05^{\prime} \mathrm{N}$, longitude $42^{\circ} 39^{\prime} \mathrm{W}$, approximate altitude $1150 \mathrm{~m}$, with no slope. These two study zones were chosen because they are characteristic of most of the heathlands. Both zones also reflect the typical distribution pattern in shrub community patches after sheep grazing has stopped.

The heathland community present in both zones is classified as a variant of the Genistelo tridentatae-Ericetum aragonensis-Cytisetosum laurifolii community, with Erica australis subsp. aragonensis as the dominant species (Willk) (Rívas Martínez et al., 1987). In zone A, Erica

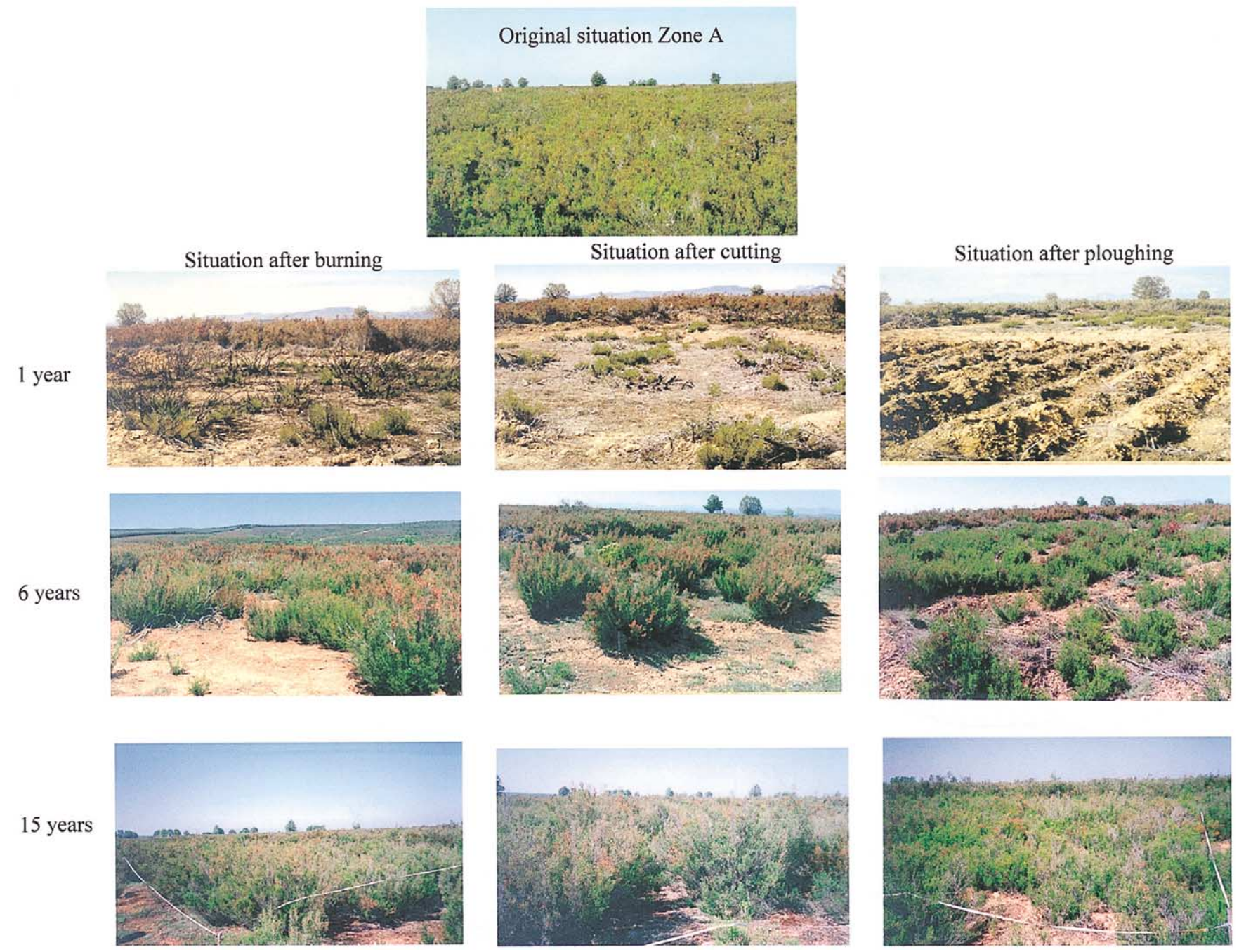

Fig. 1. Photos of the original situation, and 1, 6 and 15 years after burning, cutting and ploughing in zone A. 


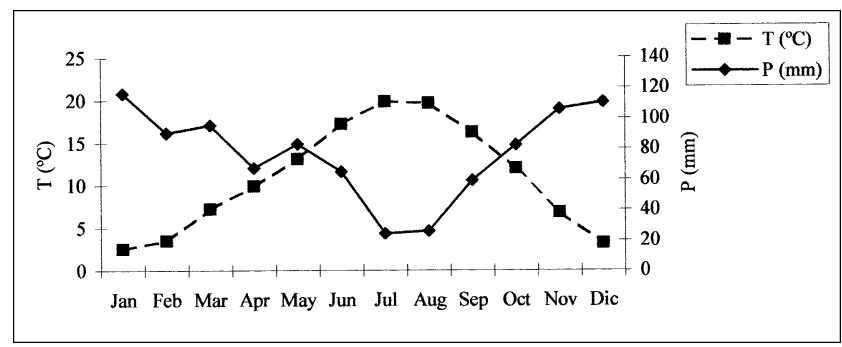

Fig. 2. Climatic diagram of the study zones (1973-1999).

australis was very dominant in the original state (Fig. 1). In zone $\mathrm{B}$, however, other woody species were also widely represented by the following chamaephytes: Arctostaphylos uva-ursi, Erica umbellata, Calluna vulgaris, Chamaespartium tridentatum, Halimium alyssoides, Halimium umbellatum and by the phanerophyte Quercus pyrenaica in a shrubby state. Both zones have basically been used in the same traditional way: sheep grazing followed by abandonment. As a result, both were similar in the initial situation, the main difference being that the richness of woody species was greater in zone B than in zone A.

Fig. 2 shows the climatic diagram, which characterises both study areas according to Ministry of Agriculture data (Ministerio de Agricultura, 1980). The areas are included in the Mediterranean climatic zone as they experience a period of summer drought between July and August. The mean annual precipitation value is $840 \mathrm{~mm}$ and the mean annual temperature is $10.3{ }^{\circ} \mathrm{C}$, the mean minimum in the coldest month is $-1.1^{\circ} \mathrm{C}$ and the mean maximum in the warmest month is $26.9^{\circ} \mathrm{C}$. However, 1988 and 1989 , when mean annual precipitation was very high at 991.4 and $941.4 \mathrm{~mm}$, respectively, and 1995, which was excessively dry $(440 \mathrm{~mm})$, should be highlighted.

From an edaphic point of view, the soil of both communities is classified as a humic cambisol (Junta de Castilla y León, 1987). Physico-chemical parameters of the soil of each community were studied (Table 1) to determine whether structure values for both indicate reasonable stability, that is to say, they are not easily erodible (Cecconi and Polesello, 1962). According to granulometric analysis, both areas are classified as very sandy. Organic content, as well as total nitrogen, $\mathrm{Ca}^{2+}, \mathrm{K}^{+}$and $\mathrm{Mg}^{2+}$, is higher in zone $\mathrm{B}$ than in A, whilst total phosphorus and assimilable phosphorus are higher in zone A. Both areas have acid soils $(\mathrm{pH}=5.5)$.

In each zone, a system of three plots, each measuring $100 \mathrm{~m}^{2}$, with a $3 \mathrm{~m}$ wide corridor in-between, was established in those areas with the most homogeneous characteristics possible in terms of species cover and height. Before treatments were applied, a vegetation inventory was carried out on 100 units of $1 \mathrm{~m}^{2}$, covering the whole plot surface. Cover percentages of all the woody species were visually estimated in each sampling unit, whereas the herbaceous species were considered as a whole because they represented a very low percentage of the total cover $(<1 \%)$.

One plot was burnt by an experimental fire. No aboveground biomass survived the burning. In the second plot, all the woody aboveground biomass was first cut to ground level using an undergrowth clearing machine and then cut down to ground level manually. All the cut biomass was dried and weighed to estimate the biomass of woody species in dry weight (Luis et al., 1989b). The mean of aboveground biomass (as dry weight) from the Erica australis in zone A was $931 \mathrm{~g} / \mathrm{m}^{2}$. In zone $\mathrm{B}$, mean aboveground biomass from the woody species were: Erica australis $161 \mathrm{~g} / \mathrm{m}^{2}$; Erica umbellata $73 \mathrm{~g} / \mathrm{m}^{2}$; Calluna vulgaris $67 \mathrm{~g} / \mathrm{m}^{2}$; Arctostaphylos uva-ursi $34 \mathrm{~g} / \mathrm{m}^{2}$; Halimium alyssoides $4 \mathrm{~g} / \mathrm{m}^{2}$; Chamaespartium tridentatum $5 \mathrm{~g} / \mathrm{m}^{2}$. The third plot was ploughed by mechanical means (with a tractor: the ploughing depth was $50 \mathrm{~cm}$ ). All the vegetation stumps were eliminated by this treatment in order to prevent vegetative sprouting. The treatments were carried out in July 1985, except for the ploughing in zone A, which was in 1986. Starting from the second year after treatments (from 1987 to 2000), five sampling units measuring $1 \mathrm{~m}^{2}$ each were studied annually in each plot. These units were sorted at random for the first sampling and marked for later visits. Percentage cover in vertical projection for each species (herbaceous and woody) was evaluated for each sampling unit. The cover values were evaluated in the same way as before the treatment. Percentage cover was quantified by the same people throughout the study period. From the fourth year, when the communities began to show visible differences in maximum heights of the dominant species Erica

Table 1

Results of physico-chemical analysis of soil

\begin{tabular}{|c|c|c|c|c|c|c|c|c|c|c|}
\hline \multicolumn{6}{|c|}{ Physical parameters } & & & & & \\
\hline $\mathrm{s}$ & $\begin{array}{l}\text { Humidity } \\
(\%)\end{array}$ & Structure & Sand $(\%)$ & Lime & Clay & & & & & \\
\hline Zone A & 1.70 & 43.50 & 79.05 & 14.30 & 4.95 & & & & & \\
\hline Zone B & 4.10 & 46.45 & 74.50 & 18.50 & 2.90 & & & & & \\
\hline \multicolumn{11}{|c|}{ Chemical parameters } \\
\hline & $\begin{array}{l}\mathrm{OM} \\
(\%)\end{array}$ & $\begin{array}{l}\text { CEC } \\
(\mathrm{meq} / 100 \mathrm{~g})\end{array}$ & $\begin{array}{l}\mathrm{Nt} \\
(\%)\end{array}$ & $\begin{array}{l}\mathrm{Ca}^{2+} \\
(\mathrm{mg} / \mathrm{kg})\end{array}$ & $\mathrm{K}^{+}$ & $\mathrm{Mg}^{2+}$ & $\mathrm{Na}^{+}$ & $\mathrm{P}$ & $\mathrm{P}_{2} \mathrm{O}_{5}$ & $\mathrm{pH}$ \\
\hline Zone A & 4.50 & 65.00 & 0.16 & 1.0 & 2.0 & 0.4 & 0.5 & 16 & 36.64 & 5.5 \\
\hline Zone B & 7.36 & 68.75 & 0.29 & 1.7 & 2.5 & 0.9 & 0.5 & 8 & 18.36 & 5.5 \\
\hline
\end{tabular}

$\mathrm{OM}=$ Organic matter; $\mathrm{CEC}=$ cation exchange capacity. 
australis, these values were noted for the tallest plant in each sampling unit.

Treatments were compared by a two-way (treatment and time, repeated measure) ANOVA of percentage cover, maximum height of Erica australis and floristic diversity parameters, in order to compare the regeneration of the species through time within and between treatments. The results obtained before the treatments and at the end of the study period were compared using a two-way ANOVA (zone and treatment) to examine whether or not there were significant differences between the original situation and the final sampling visit. The significance of the results was assessed using Scheffe's test (Scheffe, 1959). Plant nomenclature follows Tutin et al. (1964-1980). Floristic diversity was calculated using species richness, evenness ( $J$ ': Pielou, 1969) and gamma diversity $\left(H^{\prime}\right.$ : Shannon and Weaver, 1949).

\section{Results}

In the original situation (Tables 2-4), a difference is observed in the number of woody species in zones A and B, being higher in the latter. However, the dominant species in both zones is the same: Erica australis. The mean cover values for this species are higher in zone A (62-79\%) than in zone B (29-38\%). Similarly, average maximum heights were $120 \mathrm{~cm}$ in zone A and $80 \mathrm{~cm}$ in zone B (Calvo, 1993). Aboveground biomass values were also initially different between zones. This was higher in zone A than in zone B. As regards the cover of herbaceous species, there were no great differences between the two zones, as they did not exceed $1 \%$ cover in either case. For this reason, they were considered as a whole, and cover percentages were not differentiated by species. Therefore, in the original situation, there was uniformity within each of the studied zones, with no significant differences between the plots in terms of cover values before the treatments (Table 5). However, significant differences were found when the cover values between the study zones were compared, so they could not be considered as two replicates.

\subsection{Recovery after burning}

The highest cover values for herbaceous annuals (or therophytes according to the classical Raunkaier (1934) life forms classification) appear in the first 5 years after burning (Fig. 3), with the following being most important: Aira caryophyllea, Crucianella angustifolia and Arnoseris minima (Table 2). These species are present throughout the study period, mainly in zone A. Several other herbaceous annuals form a transient group, since they only appear in the first years following disturbance. This includes Spergula morisonii, Scleranthus annuus and Erophila verna. They are completely displaced from the zone from the fourth year, resulting in significant differences $(P<0.0005)$ between the first 3-4 years of recovery and the remainder of the study period.

Perennials behave differently, as their increase (Fig. 3) shows no significant differences over time. Perennial spe-

Table 2

Mean cover values of the most important species present in zones A and B through the study period after the burning treatment $(\mathrm{B})$. $0=$ Original situation; 1, 3, 4, 5, 6, 7, ..15 = years after burning. Biological traits: $\mathrm{A}=$ annual herbaceous; $\mathrm{P}=$ perennial herbaceous; $\mathrm{W}=$ woody species. Life forms: $\mathrm{T}=$ therophytes; $\mathrm{H}=$ hemicryptophytes; $\mathrm{C}=$ chamaephytes

$\begin{array}{lllllllllllllllll}\text { Biological } & \text { Life } & \text { B0 } & \text { B2 } & \text { B3 } & \text { B4 } & \text { B5 } & \text { B6 } & \text { B7 } & \text { B8 } & \text { B9 } & \text { B10 } & \text { B11 } & \text { B12 } & \text { B13 } & \text { B14 } & \text { B15 }\end{array}$

traits forms

\begin{tabular}{ll}
\hline Zone A & \\
Aira caryophyllea & $\mathrm{A}$ \\
Arnoseris minima & $\mathrm{A}$ \\
Crucianella angustifolia & $\mathrm{A}$ \\
Arenaria montana & $\mathrm{P}$ \\
Avenula marginata & $\mathrm{P}$ \\
Centaurea janeri & $\mathrm{P}$ \\
Hypochaeris radicata & $\mathrm{P}$ \\
Lotus corniculatus & $\mathrm{P}$ \\
Erica australis & $\mathrm{W}$ \\
Thymus zygis & $\mathrm{W}$ \\
Zone B & \\
Aira caryophyllea & $\mathrm{A}$ \\
Arnoseris minima & $\mathrm{A}$ \\
Crucianella angustifolia & $\mathrm{A}$ \\
Arenaria montana & $\mathrm{P}$ \\
Avenula marginata & $\mathrm{P}$ \\
Hypochoeris radicata & $\mathrm{P}$ \\
Tuberaria globularifolia & $\mathrm{P}$ \\
Arctostaphylos uva-ursi & $\mathrm{W}$ \\
Calluna vulgaris & $\mathrm{W}$ \\
Erica australis & $\mathrm{W}$ \\
Erica umbellat & $\mathrm{W}$ \\
Halimium alyssoides & $\mathrm{W}$ \\
\hline
\end{tabular}

$\mathrm{T}$

$\begin{array}{llll}\mathrm{T} & 3.0 & 5.0 & 3.4\end{array}$

$\mathrm{H}$

$\mathrm{H}$

$\mathrm{H}$

$\mathrm{H}$

$\mathrm{H}$

C

$\mathrm{T}$

$\mathrm{T}$

$\mathrm{T}$

$\mathrm{H}$

$\mathrm{H}$

$\mathrm{H}$

C

C

C

$\mathrm{C}$
$\mathrm{C}$

\begin{tabular}{|c|c|c|c|c|c|c|c|c|c|c|c|c|c|c|}
\hline & 3.0 & 5.0 & 3.4 & 2.4 & 2.2 & 0.8 & 0.6 & 1.0 & 0.0 & 1.4 & 0.4 & 0.6 & 0.0 & 0.2 \\
\hline & 0.8 & 1.0 & 1.0 & 0.6 & 0.4 & 0.2 & 0.0 & 0.6 & 0.0 & 0.4 & 0.6 & 0.0 & 0.2 & 0.2 \\
\hline & 0.6 & 0.6 & 1.2 & 0.6 & 0.8 & 0.6 & 0.8 & 0.4 & 0.2 & 0.6 & 0.2 & 0.8 & 0.8 & 0.2 \\
\hline & 2.6 & 1.4 & 2.2 & 1.2 & 0.8 & 2.2 & 1.8 & 1.0 & 1.0 & 1.8 & 2.2 & 1.6 & 1.4 & 0.2 \\
\hline & 0.6 & 2.6 & 3.2 & 8.4 & 3.0 & 4.6 & 4.4 & 5.2 & 4.2 & 3.6 & 6.2 & 9.2 & 5.8 & 5.0 \\
\hline & 2.0 & 0.8 & 3.0 & 2.0 & 4.2 & 2.4 & 5.0 & 7.0 & 3.2 & 4.6 & 4.4 & 5.0 & 7.6 & 1.0 \\
\hline & 0.8 & 3.4 & 3.0 & 1.4 & 3.8 & 4.6 & 3.4 & 3.0 & 3.4 & 4.4 & 3.4 & 3.2 & 2.2 & 4.4 \\
\hline & 8.6 & 13.2 & 0.8 & 2.0 & 5.8 & 1.8 & 2.2 & 2.8 & 2.0 & 3.4 & 3.2 & 3.6 & 1.8 & 0.8 \\
\hline \multirow[t]{9}{*}{78.7} & 16.0 & 17.0 & 37.0 & 47.0 & 34.0 & 36.0 & 44.0 & 41.0 & 50.0 & 42.6 & 51.0 & 43.0 & 45.0 & 47.0 \\
\hline & 2.8 & 3.0 & 3.6 & 2.0 & 2.6 & 1.5 & 1.8 & 1.6 & 1.5 & 1.5 & 2.0 & 2.0 & 2.0 & 1.0 \\
\hline & 13.0 & 5.2 & 6.0 & 2.2 & 1.0 & 0.0 & 0.0 & 0.0 & 0.0 & 0.4 & 0.4 & 0.0 & 0.0 & 0.0 \\
\hline & 1.2 & 1.2 & 0.8 & 1.2 & 0.4 & 0.0 & 0.0 & 0.0 & 0.0 & 0.0 & 0.0 & 0.0 & 0.0 & 0.0 \\
\hline & 0.4 & 0.4 & 0.2 & 1.2 & 0.2 & 0.0 & 0.0 & 0.0 & 0.0 & 0.0 & 0.0 & 0.0 & 0.0 & 0.0 \\
\hline & 0.0 & 1.0 & 1.0 & 0.6 & 1.0 & 0.4 & 0.0 & 0.6 & 0.0 & 1.2 & 0.2 & 0.6 & 0.6 & 0.0 \\
\hline & 4.0 & 2.2 & 2.2 & 1.8 & 2.0 & 1.4 & 3.6 & 1.8 & 0.6 & 1.2 & 1.2 & 2.2 & 2.2 & 0.2 \\
\hline & 2.8 & 2.8 & 1.8 & 2.0 & 0.8 & 1.6 & 1.2 & 0.6 & 0.0 & 0.4 & 0.6 & 0.6 & 0.0 & 0.0 \\
\hline & 2.4 & 2.4 & 4.4 & 2.8 & 2.2 & 1.8 & 1.6 & 1.4 & 0.6 & 0.4 & 0.8 & 1.2 & 0.0 & 0.0 \\
\hline 43.6 & 27.0 & 21.0 & 25.0 & 23.2 & 43.0 & 38.0 & 55.0 & 50.0 & 46.0 & 38.0 & 41.0 & 49.0 & 57.8 & 52.0 \\
\hline 21.5 & 0.0 & 0.0 & 2.0 & 1.4 & 3.2 & 3.8 & 7.6 & 7.2 & 6.0 & 8.4 & 10.2 & 11.0 & 17.0 & 17.0 \\
\hline 31.4 & 25.4 & 30.0 & 34.0 & 44.0 & 43.0 & 48.0 & 64.0 & 67.0 & 67.0 & 65.0 & 55.0 & 55.0 & 39.0 & 38.0 \\
\hline 17.6 & 0.0 & 0.0 & 1.6 & 3.0 & 3.6 & 3.0 & 4.4 & 8.6 & 8.0 & 14.0 & 12.0 & 24.0 & 27.0 & 34.0 \\
\hline 3.9 & 2.8 & 2.0 & 2.2 & 3.4 & 3.6 & 6.0 & 5.8 & 6.2 & 4.6 & 4.6 & 5.6 & 4.0 & 6.0 & 5.0 \\
\hline
\end{tabular}


Table 3

Mean cover values of the most important species present in zones A and B through the study period after the cutting treatment $(\mathrm{C}) .0=$ Original situation; $2,3,4,5,6,7, \ldots 15=$ years after cutting. Biological traits: $\mathrm{A}=$ annual herbaceous; $\mathrm{P}=$ perennial herbaceous; $\mathrm{W}=$ woody species. Life forms: $\mathrm{T}=$ therophytes; $\mathrm{H}=$ hemicryptophytes $; \mathrm{C}=$ chamaephytes

\begin{tabular}{|c|c|c|c|c|c|c|c|c|c|c|c|c|c|c|c|c|c|}
\hline & $\begin{array}{l}\text { Biological } \\
\text { traits }\end{array}$ & $\begin{array}{l}\text { Life } \\
\text { forms }\end{array}$ & $\mathrm{C} 0$ & $\mathrm{C} 2$ & $\mathrm{C} 3$ & $\mathrm{C} 4$ & C5 & C6 & $\mathrm{C} 7$ & $\mathrm{C} 8$ & C9 & $\mathrm{C} 10$ & $\mathrm{C} 11$ & $\mathrm{C} 12$ & $\mathrm{C} 13$ & $\mathrm{C} 14$ & $\mathrm{C} 15$ \\
\hline \multicolumn{18}{|l|}{ Zone A } \\
\hline Aira caryophyllea & A & $\mathrm{T}$ & & 0.2 & 0.2 & 1.2 & 1.2 & 0.4 & 0.0 & 0.2 & 0.6 & 0.2 & 0.2 & 1.0 & 0.4 & 0.6 & 0.4 \\
\hline Andryala integrifolia & A & $\mathrm{T}$ & & 0.8 & 0.6 & 1.0 & 0.4 & 0.0 & 0.0 & 0.8 & 0.4 & 1.2 & 0.2 & 0.2 & 0.2 & 1.0 & 0.2 \\
\hline Arnoseris minima & A & $\mathrm{T}$ & & 0.4 & 0.6 & 1.6 & 0.4 & 0.2 & 0.4 & 0.2 & 0.2 & 0.0 & 0.4 & 0.2 & 1.2 & 0.2 & 0.4 \\
\hline Jasione montana & A & $\mathrm{T}$ & & 0.0 & 0.4 & 1.2 & 0.6 & 0.4 & 0.0 & 0.0 & 0.2 & 0.2 & 0.8 & 0.6 & 2.6 & 1.0 & 1.6 \\
\hline Avenula marginata & $\mathrm{P}$ & $\mathrm{H}$ & & 2.4 & 6.0 & 3.4 & 6.6 & 0.0 & 5.4 & 4.8 & 5.6 & 10.4 & 6.0 & 6.0 & 9.2 & 10.0 & 15.2 \\
\hline Centaurea janeri & $\mathrm{P}$ & $\mathrm{H}$ & & 1.2 & 2.8 & 4.0 & 1.6 & 4.0 & 1.8 & 2.4 & 4.6 & 5.6 & 2.0 & 3.8 & 4.2 & 4.8 & 6.6 \\
\hline Hypochoeris radicata & $\mathrm{P}$ & $\mathrm{H}$ & & 1.2 & 1.4 & 1.6 & 2.6 & 3.0 & 0.8 & 2.8 & 2.0 & 1.2 & 3.0 & 4.0 & 3.8 & 6.0 & 1.4 \\
\hline Plantago holosteum & $\mathrm{P}$ & $\mathrm{H}$ & & 1.2 & 2.0 & 0.8 & 1.2 & 2.0 & 1.6 & 2.2 & 2.8 & 0.8 & 1.8 & 3.0 & 1.6 & 2.6 & 0.6 \\
\hline Viola riviniana & $\mathrm{P}$ & $\mathrm{H}$ & & 0.6 & 1.2 & 1.0 & 0.6 & 1.6 & 1.6 & 3.2 & 1.2 & 0.6 & 1.2 & 2.6 & 2.4 & 2.2 & 1.4 \\
\hline Erica australis & W & $\mathrm{C}$ & 62.2 & 25.4 & 26.4 & 45.0 & 47.3 & 53.6 & 53.0 & 62.0 & 54.0 & 52.0 & 52.0 & 50.0 & 48.0 & 59.0 & 50.0 \\
\hline Thymus zygis & $\mathrm{W}$ & $\mathrm{C}$ & 1.2 & 1.2 & 2.4 & 3.6 & 3.0 & 2.8 & 3.0 & 3.6 & 4.0 & 2.0 & 2.2 & 1.2 & 2.0 & 2.0 & 2.2 \\
\hline \multicolumn{18}{|l|}{ Zone B } \\
\hline Aira caryophyllea & A & $\mathrm{T}$ & & 22.0 & 15.0 & 3.0 & 1.4 & 0.6 & 0.0 & 0.0 & 0.0 & 0.0 & 0.0 & 0.0 & 0.0 & 0.0 & 0.0 \\
\hline Tuberaria guttata & A & $\mathrm{T}$ & & 2.6 & 1.4 & 0.4 & 0.4 & 0.0 & 0.2 & 0.0 & 0.0 & 0.0 & 0.0 & 0.0 & 0.0 & 0.0 & 0.0 \\
\hline Tuberaria globularifolia & $\mathrm{P}$ & $\mathrm{H}$ & & 1.4 & 4.2 & 5.2 & 3.8 & 3.0 & 2.6 & 1.6 & 0.4 & 0.2 & 0.2 & 0.6 & 0.6 & 0.2 & 0.4 \\
\hline Lolium perenne & $\mathrm{P}$ & $\mathrm{H}$ & & 0.8 & 0.8 & 1.2 & 0.2 & 0.0 & 0.0 & 0.0 & 0.0 & 0.0 & 0.0 & 0.0 & 0.0 & 0.0 & 0.0 \\
\hline Arctostaphylos uva-ursi & $\mathrm{W}$ & $\mathrm{C}$ & 28.6 & & & & & & & & & & & & & & \\
\hline Calluna vulgaris & W & $\mathrm{C}$ & 17.8 & 1.0 & 0.8 & 3.6 & 3.6 & 5.8 & 8.6 & 7.2 & 6.6 & 5.0 & 6.0 & 7.0 & 7.0 & 5.0 & 14.6 \\
\hline Erica australis & $\mathrm{W}$ & $\mathrm{C}$ & 28.6 & 7.0 & 28.8 & 34.0 & 34.0 & 43.0 & 35.0 & 30.0 & 43.2 & 43.0 & 30.0 & 45.2 & 36.0 & 35.0 & 48.0 \\
\hline Erica umbellata & $\mathrm{W}$ & $\mathrm{C}$ & 38.4 & 2.0 & 2.8 & 2.8 & 10.6 & 15.2 & 25.0 & 39.0 & 27.0 & 25.0 & 34.0 & 30.0 & 54.0 & 51.0 & 43.0 \\
\hline Halimium alyssoides & $\mathrm{W}$ & $\mathrm{C}$ & 6.7 & 2.2 & 5.0 & 9.6 & 7.2 & 6.8 & 12.6 & 11.7 & 11.6 & 12.0 & 10.0 & 13.0 & 12.0 & 12.0 & 11.0 \\
\hline Halimium umbellatum & $\mathrm{W}$ & $\mathrm{C}$ & 0.4 & 2.2 & 2.6 & 2.6 & 4.6 & 3.8 & 5.6 & 3.6 & 3.2 & 1.0 & 0.4 & 1.0 & 1.5 & 1.0 & 1.2 \\
\hline
\end{tabular}

Table 4

Mean cover values of the most important species present in zones A and B through the study period after the ploughing treatment $(\mathrm{P}) .0=$ Original situation; $2,3,4,5,6,7, \ldots 15=$ years after ploughing. Biological traits: $\mathrm{A}=$ annual herbaceous; $\mathrm{P}=$ perennial herbaceous; $\mathrm{W}=$ woody species. Life forms: $\mathrm{T}=$ therophytes; $\mathrm{H}=$ hemicryptophytes; $\mathrm{C}=$ chamaephytes

\begin{tabular}{|c|c|c|c|c|c|c|c|c|c|c|c|c|c|c|c|c|c|}
\hline & $\begin{array}{l}\text { Biological } \\
\text { traits }\end{array}$ & $\begin{array}{l}\text { Life } \\
\text { forms }\end{array}$ & P0 & P2 & P3 & P4 & P5 & P6 & P7 & P8 & P9 & P10 & P11 & $\mathrm{P} 12$ & P13 & P14 & P15 \\
\hline \multicolumn{18}{|l|}{ Zone A } \\
\hline Aira caryophyllea & A & $\mathrm{T}$ & & 1.6 & 3.2 & 4.4 & 2.4 & 0.0 & 0.6 & 0.0 & 0.0 & 0.2 & 0.2 & 0.2 & 0.0 & 0.0 & \\
\hline Arnoseris minima & $\mathrm{A}$ & $\mathrm{T}$ & & 1.2 & 0.8 & 0.4 & 0.0 & 0.6 & 0.0 & 0.0 & 0.0 & 0.0 & 0.0 & 0.0 & 0.0 & 0.0 & \\
\hline Logfia minima & A & $\mathrm{T}$ & & 2.4 & 0.0 & 1.0 & 0.8 & 0.0 & 0.0 & 0.0 & 0.0 & 0.0 & 0.0 & 0.6 & 0.0 & 0.0 & \\
\hline Agrostis capillaris & $\mathrm{P}$ & $\mathrm{H}$ & & 0.0 & 0.8 & 3.2 & 0.4 & 1.0 & 1.4 & 0.8 & 0.0 & 1.0 & 0.6 & 1.0 & 1.6 & 0.2 & \\
\hline Avenula marginata & $\mathrm{P}$ & $\mathrm{H}$ & & 2.0 & 3.2 & 2.4 & 8.2 & 12.6 & 13.6 & 10.8 & 12.0 & 6.4 & 12.2 & 11.2 & 17.0 & 7.2 & \\
\hline Hypochoeris radicata & $\mathrm{P}$ & $\mathrm{H}$ & & 1.6 & 2.0 & 2.4 & 2.4 & 0.0 & 0.0 & 0.2 & 0.2 & 0.0 & 0.2 & 0.8 & 0.4 & 0.0 & \\
\hline Lolium perenne & $\mathrm{P}$ & $\mathrm{H}$ & & 1.0 & 2.0 & 1.0 & 1.2 & 0.6 & 0.0 & 0.0 & 0.0 & 0.2 & 0.0 & 0.2 & 0.2 & 0.0 & \\
\hline Lotus corniculatus & $\mathrm{P}$ & $\mathrm{H}$ & & 3.6 & 0.4 & 3.4 & 5.8 & 0.4 & 1.0 & 0.6 & 0.4 & 0.4 & 1.0 & 1.6 & 1.0 & 0.4 & \\
\hline $\begin{array}{l}\text { Erica australis } \\
\text { Zone B }\end{array}$ & $\mathrm{W}$ & $\mathrm{C}$ & 81.0 & 1.0 & 15.0 & 29.0 & 30.0 & 41.0 & 51.0 & 61.0 & 59.0 & 55.0 & 55.0 & 58.0 & 59.0 & 65.0 & \\
\hline Aira caryophyllea & A & $\mathrm{T}$ & & 15 & 26.0 & 11.0 & 2.0 & 1.4 & 0.6 & 4.2 & 1.0 & 1.0 & 0.8 & 0.2 & 0.2 & 1.0 & 0.2 \\
\hline Arnoseris minima & A & $\mathrm{T}$ & & 1.4 & 0.8 & 1.2 & 1.6 & 0.8 & 0.0 & 0.0 & 0.0 & 0.0 & 0.2 & 0.0 & 0.0 & 0.0 & 0.2 \\
\hline Evax carpetana & A & $\mathrm{T}$ & & 1.4 & 5.6 & 1.4 & 1.0 & 0.0 & 0.4 & 0.0 & 0.4 & 0.0 & 0.0 & 0.0 & 0.0 & 0.0 & 0.0 \\
\hline Logfia minima & A & $\mathrm{T}$ & & 1 & 0.0 & 0.4 & 0.0 & 0.0 & 0.0 & 0.0 & 0.0 & 0.0 & 0.0 & 0.0 & 0.0 & 0.0 & 0.0 \\
\hline Scleranthus аппииs & A & $\mathrm{T}$ & & 1.6 & 3.0 & 1.4 & 0.6 & 0.4 & 0.2 & 0.2 & 0.0 & 0.2 & 0.4 & 0.0 & 1.0 & 1.8 & 0.2 \\
\hline Agrostis capillaris & $\mathrm{P}$ & $\mathrm{H}$ & & 0 & 4.0 & 3.2 & 5.0 & 3.2 & 3.0 & 5.0 & 0.4 & 0.2 & 0.4 & 0.6 & 1.0 & 0.2 & 0.6 \\
\hline Hieracium castellanum & $\mathrm{P}$ & $\mathrm{H}$ & & 0 & 0.6 & 1.4 & 0.2 & 1.2 & 1.8 & 0.0 & 1.2 & 0.8 & 1.4 & 2.0 & 3.0 & 0.0 & 2.0 \\
\hline Hypochoeris radicata & $\mathrm{P}$ & $\mathrm{H}$ & & 0.2 & 2.0 & 5.0 & 2.0 & 1.2 & 1.2 & 0.2 & 0.8 & 0.4 & 0.2 & 0.2 & 0.0 & 0.2 & 0.0 \\
\hline Lolium perenne & $\mathrm{P}$ & $\mathrm{H}$ & & 2.6 & 2.4 & 1.8 & 1.0 & 1.0 & 0.4 & 0.0 & 0.2 & 0.2 & 0.2 & 0.0 & 0.0 & 0.4 & 0.2 \\
\hline Lotus corniculatus & $\mathrm{P}$ & $\mathrm{H}$ & & 0.2 & 0.0 & 0.4 & 0.8 & 0.6 & 0.0 & 0.2 & 0.2 & 0.0 & 0.4 & 0.0 & 1.0 & 0.0 & 0.0 \\
\hline Sanguisorba minor & $\mathrm{P}$ & $\mathrm{H}$ & & 0.8 & 2.4 & 4.0 & 0.6 & 3.0 & 3.6 & 1.8 & 2.0 & 1.2 & 1.4 & 1.6 & 1.2 & 0.0 & 0.2 \\
\hline Arctostaphylos uva-ursi & $\mathrm{W}$ & $\mathrm{C}$ & 43.1 & 0.4 & 0.4 & 0.4 & 2.0 & 2.0 & 1.5 & 0.6 & 0.6 & 2.0 & 2.0 & 1.0 & 2.0 & 2.0 & 3.2 \\
\hline Calluna vulgaris & $\mathrm{W}$ & $\mathrm{C}$ & 25.1 & 0 & 0.6 & 4.0 & 9.2 & 12.6 & 12.0 & 19.6 & 18.6 & 18.6 & 22.0 & 26.6 & 33.0 & 25.0 & 41.0 \\
\hline Erica australis & $\mathrm{W}$ & $\mathrm{C}$ & 38.3 & 0 & 5.6 & 12.0 & 14.2 & 18.6 & 14.0 & 14.0 & 15.6 & 16.0 & 14.0 & 18.0 & 18.0 & 18.0 & 26.0 \\
\hline Erica umbellata & W & $\mathrm{C}$ & 5.0 & 0 & 0.0 & 0.0 & 1.6 & 4.4 & 5.0 & 7.0 & 3.6 & 2.6 & 7.0 & 6.0 & 9.0 & 10.0 & 13.0 \\
\hline Halimium alyssoides & $\mathrm{W}$ & $\mathrm{C}$ & 5.8 & 1.6 & 10.4 & 24.0 & 18.6 & 36.2 & 32.0 & 32.6 & 30.6 & 28.0 & 26.0 & 25.0 & 23.0 & 23.0 & 21.2 \\
\hline
\end{tabular}


Table 5

Two-factor ANOVA comparing the original situation in each zone (plots that will be submitted to experimental treatment) and between both zones

\begin{tabular}{lrlll}
\hline Source & df & Mean square & $F$-test & $P$ value \\
\hline Zone (A) & 1 & 14300.83 & 17.58 & 0.0003 \\
Treatments (B) & 2 & 751.9 & 0.925 & 0.4103 \\
AB & 2 & 108.03 & 0.133 & 0.876 \\
Error & 24 & 813.15 & & \\
\hline
\end{tabular}

cies (or hemicryptophytes) with high cover values are Avenula marginata, Arenaria montana and Hypochoeris radicata. Lotus corniculatus and Centaurea janeri are also of note in zone A, while Tuberaria globularifolia occurs only in zone B (Table 2). It is important to emphasise that in the zone where there is a clear dominance of woody species (zone B), the number and cover of herbaceous taxa is very small. The space occupied by woody plants impedes the development and maintenance of herbaceous species for a long time.

Woody species increase their cover values significantly over time (Fig. 3), although these increases are no longer significant from year 5 in zone A and from year 8 in zone B. The first woody species to appear are those with a vegetative sprouting capacity, like the chamaephytes: Erica australis and Arctostaphylos uva-ursi. Erica australis is the dominant species in both zones initially and after burning (Table 2). In the case of species using germination as a recovery mechanism (Halimium alyssoides, Halimium umbellatum and Thymus zygis), cover values after 2 years are relatively low, although there is a slight increase over time.
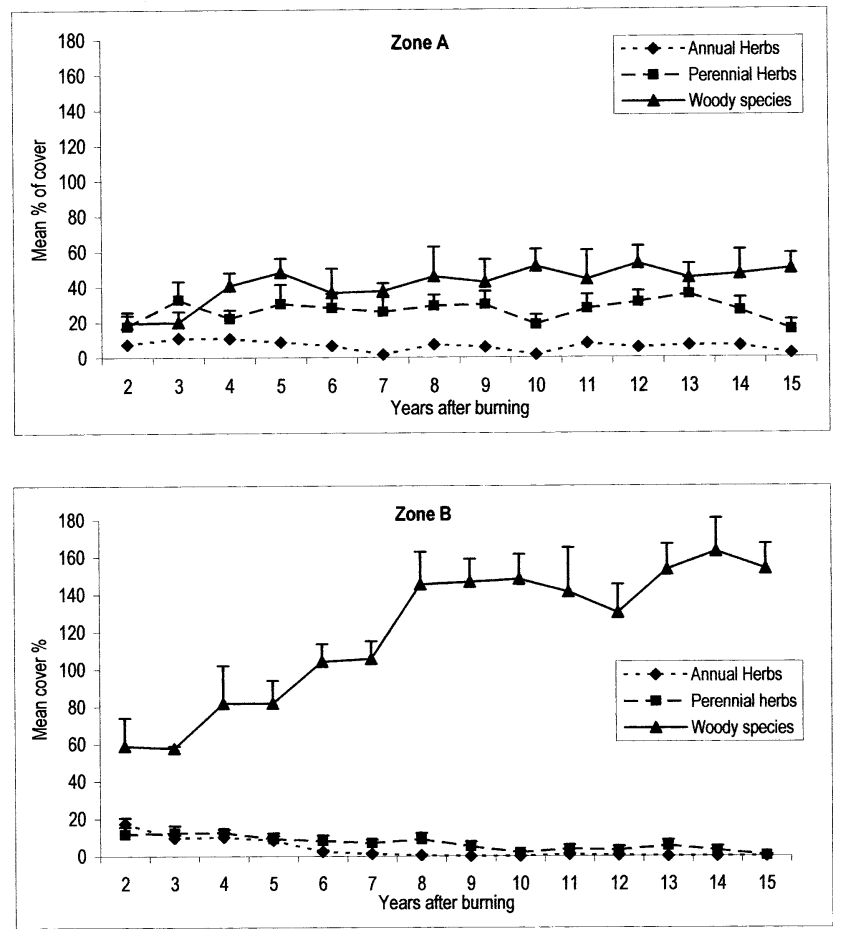

Fig. 3. Mean percentage cover and standard error of annual herbaceous, perennial herbaceous and woody species after burning in zones A and B. 2, $3,4,{ }^{\prime} 15=$ Years after burning.
After the first recovery phases, woody species, which were present in the original situation, reappear in both zones.

\subsection{Recovery after cutting}

The response of the community to cutting follows a pattern similar to regeneration after burning. The main difference between these two treatments appears in the percentage cover of the herbaceous species during the first few years. These are higher after cutting than after burning, as the herbaceous species remain in the cut plot during the experimental treatment. The highest cover values for herbaceous annuals appear in the first years (Fig. 4). One notable aspect is that in zone B, cover values for annuals are higher than those of woody species during the second year, due to the abundance of Aira caryophyllea (Table 3). From the fourth year, annuals decrease significantly in both zones, disappearing in zone B. In general, cover values for annuals are higher after burning than after cutting, either throughout the study period (zone A) or in the final years (zone B).

Herbaceous perennials have virtually constant cover values over time (Fig. 4). There are significant differences
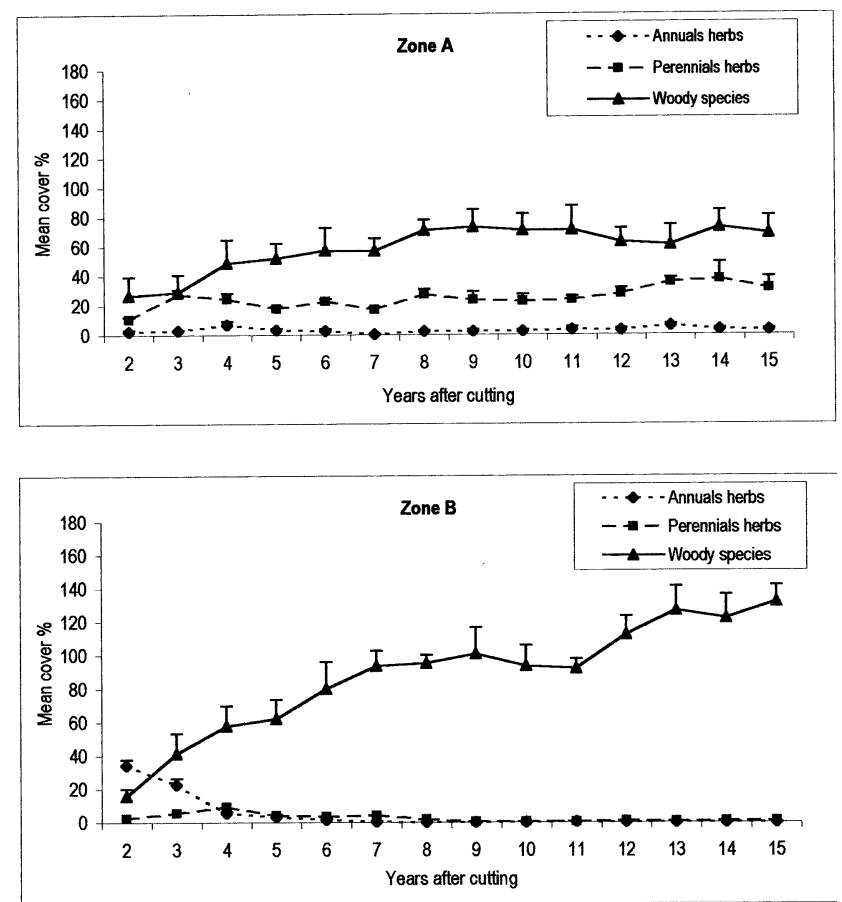

Fig. 4. Mean percentage cover and standard error of annual herbaceous, perennial herbaceous and woody species after cutting in zones A and B. 2, $3,4, ' 15=$ Years after cutting. 
only in the second year of recovery, when values are low in comparison with the other years. In zone A, Avenula marginata, Hypochoeris radicata, Plantago holosteum, Centaurea janeri and Viola riviniana have high representation throughout the study period (Table 3 ). In zone B, there is lower specific richness in this life form and a smaller contribution to recovery in terms of area. High cover values for Tuberaria globularifolia are notable. As in the burnt plot, greater cover of woody species has a negative influence on the presence of herbaceous perennials.

The behaviour of woody species is similar to that after burning, with a significant increase in cover values over time (Fig. 4), although this increase is smaller than in the case of burning. The species that recover first are resprouters, mainly Erica australis. It is important to note that the sprouting woody species Arctostaphylos uva-ursi does not recover after cutting.

\subsection{Recovery after ploughing}

Recovery after ploughing is slower than in the other two cases. It is the only treatment in which the herbaceous species dominate in both zones during the second to third years (Fig. 5). Annual herbaceous species (Table 4) with high cover values in both zones are Aira caryophyllea, Scleranthus annuus, Evax carpetana, Arnoseris minima and Logfia minima. Lolium perenne, Lotus corniculatus and Hypochoeris radicata are of note among the perennial herbaceous species.

Woody species begin to dominate in both zones from the fourth year (Fig. 5). In this treatment, all the woody species appearing are the result of seed germination, and consequently, a longer period is required for recovery to start. There is a significant increase in cover over time. The species that begin to recover 2 years after ploughing are
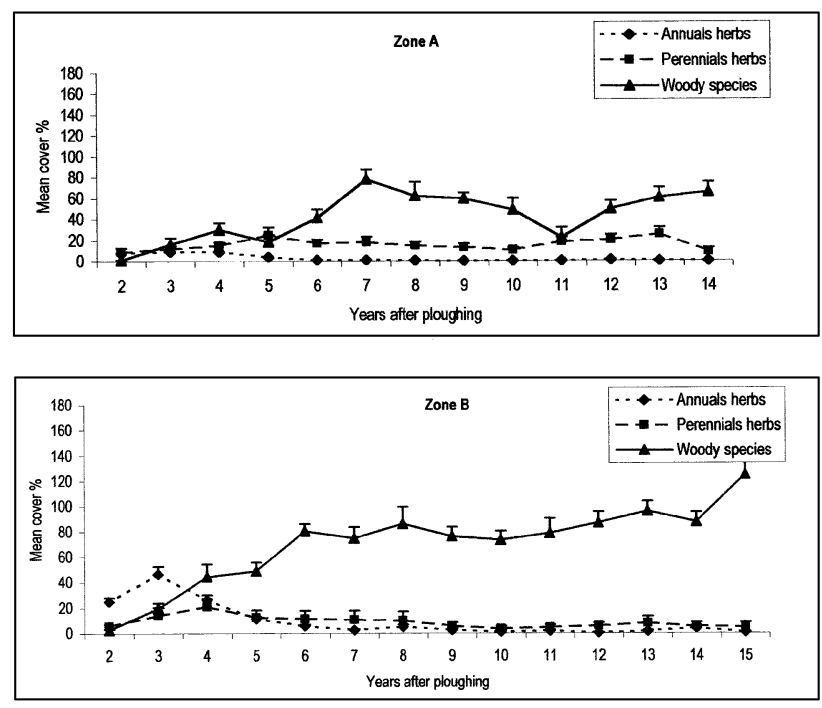

Fig. 5. Mean percentage cover and standard error of annual herbaceous, perennial herbaceous and woody species after ploughing in zones A and B. $2,3,4,{ }^{\prime} 15=$ Years after ploughing.
Erica australis with very low values and Halimium alyssoides and Halimium umbellatum with much higher values in zone B. The latter two species have higher cover values after this treatment than after cutting and burning. Arctostaphylos uva-ursi and Chamaespartium tridentatum, which begin to germinate in this zone after 2 years, also have the capacity to recover by germination and sprouting.

\subsection{Comparison between treatments}

A comparison of the three treatments in zone A indicates that there are no significant differences $(P>0.05)$ between them throughout the study period in the cover values for either herbaceous perennials or woody species. Significant differences only appear in the herbaceous annuals between burning and the other two treatments after 6 years' study. This is because, after burning, the annuals have relatively high cover values, and they disappear after cutting and ploughing. In zone $\mathrm{B}$, herbaceous perennials show no differences $(P>0.0005)$ between the three treatments. The woody and annual herbaceous species show differences in the first stages, as the response of woody species is better after burning than after the other two treatments. The annuals attain higher values after ploughing and cutting than after burning.

When the total cover values in the final sampling after 15 years are compared using a two-way ANOVA, no significant differences are observed (Table 6) in terms of the treatment, but significantly higher cover values are still observed in zone B. The same can be said of woody cover. As regards herbaceous species, there are also significant differences between the two zones, with higher cover values in zone A. In addition, there is a significant interaction between the zone and treatment factors, with higher herbaceous cover in the cut plot and lower cover in the ploughed area in zone A, whilst the ploughed plot in zone B has the highest herbaceous cover.

When a two-way ANOVA is used to compare total cover in terms of the treatment between the original and the final situations, no significant differences are detected in zone A (Table 7) in terms of the two factors. However, the interaction between the two is significant $(P<0.01)$ : the ploughed and burnt plot cover values are slightly lower after 15 years, whilst cover in the cut plot has increased in comparison with the original situation, mainly due to herbaceous cover. There are no differences between treatments or in comparison with the original situation in zone B (Table 7).

Therefore, it can be stated that there are no significant differences between treatments in each zone after 15 years of secondary succession, although the differences between zones remain. This means that although the speed of regeneration differs after the three treatments, with ploughing being the slowest, the final recovery level is similar (Fig. 1). 
Table 6

Two-factor ANOVA comparing the situation 15 years after treatments in each zone and between both zones

\begin{tabular}{|c|c|c|c|c|}
\hline Source & df & Mean square & $F$-test & $P$ value \\
\hline \multicolumn{5}{|c|}{ Comparing by total cover } \\
\hline Zone (A) & 1 & 21067.5 & 25.727 & 0.0001 \\
\hline Treatments (B) & 2 & 265.633 & 0.324 & 0.7261 \\
\hline $\mathrm{AB}$ & 2 & 800.1 & 0.977 & 0.3909 \\
\hline Error & 24 & 818.88 & & \\
\hline \multicolumn{5}{|c|}{ Comparing by woody species cover } \\
\hline Zone (A) & 1 & 37949.633 & 52.733 & 0.0001 \\
\hline Treatments (B) & 2 & 6.1 & 0.008 & 0.9916 \\
\hline $\mathrm{AB}$ & 2 & 484.633 & 0.673 & 0.5193 \\
\hline Error & 24 & 719.65 & & \\
\hline \multicolumn{5}{|c|}{ Comparing by herbaceous species cover } \\
\hline Zone (A) & 1 & 2466.133 & 22.379 & 0.0001 \\
\hline Treatments (B) & 2 & 321.433 & 2.917 & 0.0735 \\
\hline $\mathrm{AB}$ & 2 & 556.033 & 5.046 & 0.0148 \\
\hline Error & 24 & 110.2 & & \\
\hline
\end{tabular}

Table 7

Two-factor ANOVA (treatment and time, repeated measure) comparing the situation both original and 15 years after treatments in each zone

\begin{tabular}{lrrr}
\hline Source & df & Mean square & $F$-test \\
\hline Zone A & 2 & & $P$ value \\
Treatment (A) & 12 & 40.133 & 0.115 \\
Subjects w. groups & 1 & 349.217 & 0.8924 \\
Repeated measure (B) & 2 & 58.8 & 0.13 \\
AB & 12 & 1489.6 & 3.288 \\
B $\times$ subjects w. groups & 2 & 453.083 & 0.0727 \\
Zone B & 12 & 374.7 & 0.33 \\
Treatment (A) & 1 & 1134.317 & 0.725 \\
Subjects w. groups & 2 & 1104.133 & 0.832 \\
Repeated measure (B) & 12 & 21.233 & 0.016 \\
AB & 12 & 1327.45 & 0.9842 \\
B $\times$ subjects w. groups & & \\
\end{tabular}

\subsection{Modifications in average maximum height}

of the dominant species Erica australis

One way of defining the structural characteristics of the community is by analysing the variation in the height values of its species. The dominant species, Erica australis, is used as the representative of the changes in this community. The most pronounced increase in height occurs once the plants have occupied practically all the space they had originally, and this happens from the fourth year on.

The height attained after burning is greater than that reached after cutting and ploughing, particularly in zone A (Fig. 6). Height increases in zone A throughout the study period show significant differences $(P=0.0005)$ between the three treatments. The heights attained in zone B after treatments show no significant differences. After ploughing, the increase is significant at 15 years, because it is higher than after the other two treatments. The average maximum height values in zone B surpassed the original values in the fifth year after the three experimental treatments. Original heights are not regained in any case in zone A.

Therefore, it can be stated that after 15 years of secondary succession, there are differences between the treatments in zone $\mathrm{A}$ in terms of the maximum height reached by the dominant species, Erica australis, which shows strata dis-
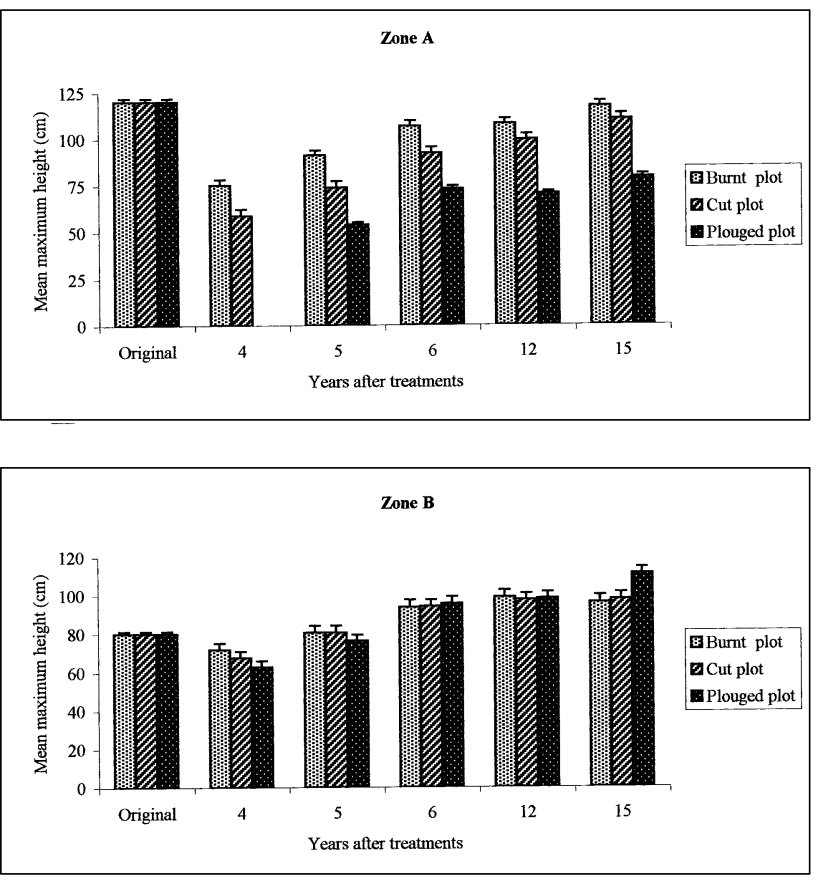

Fig. 6. Mean (and standard error) of maximum heights of Erica australis after burning, cutting and ploughing in zones A and B. $2,3,4, \ldots 15=$ Years after treatments. 


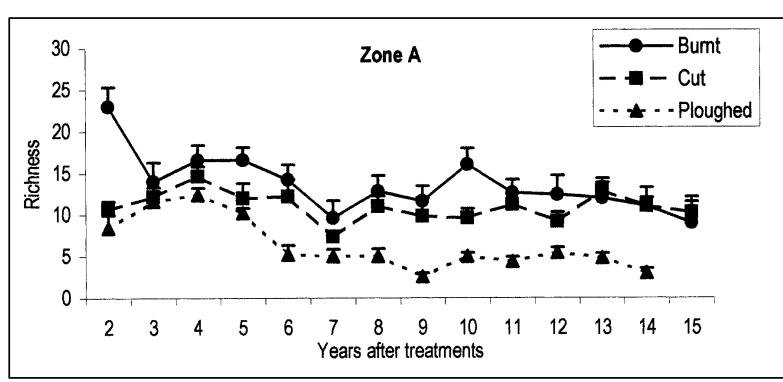

b)
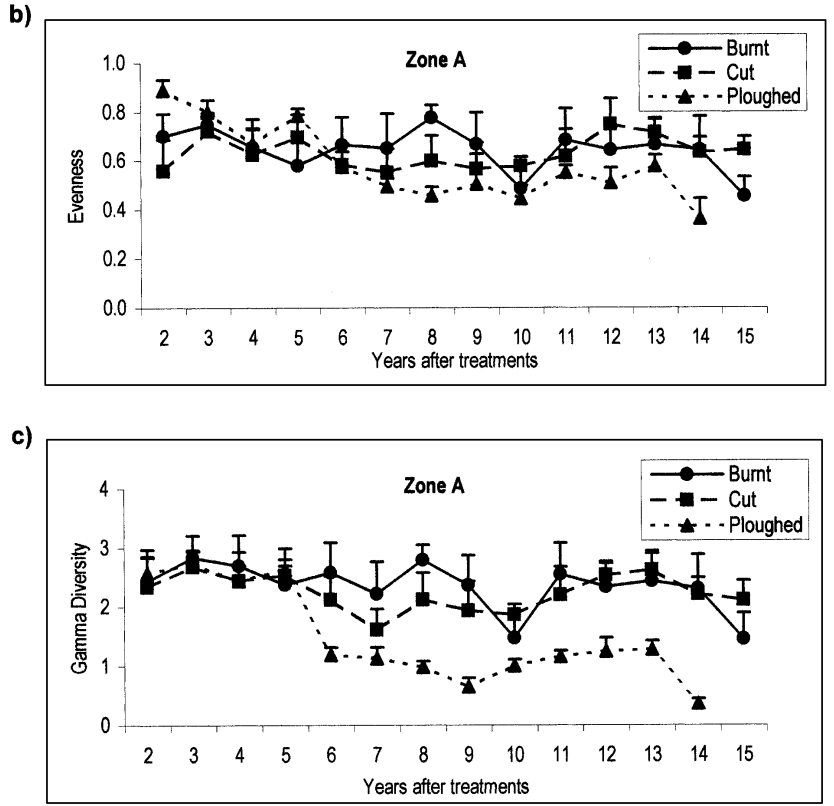
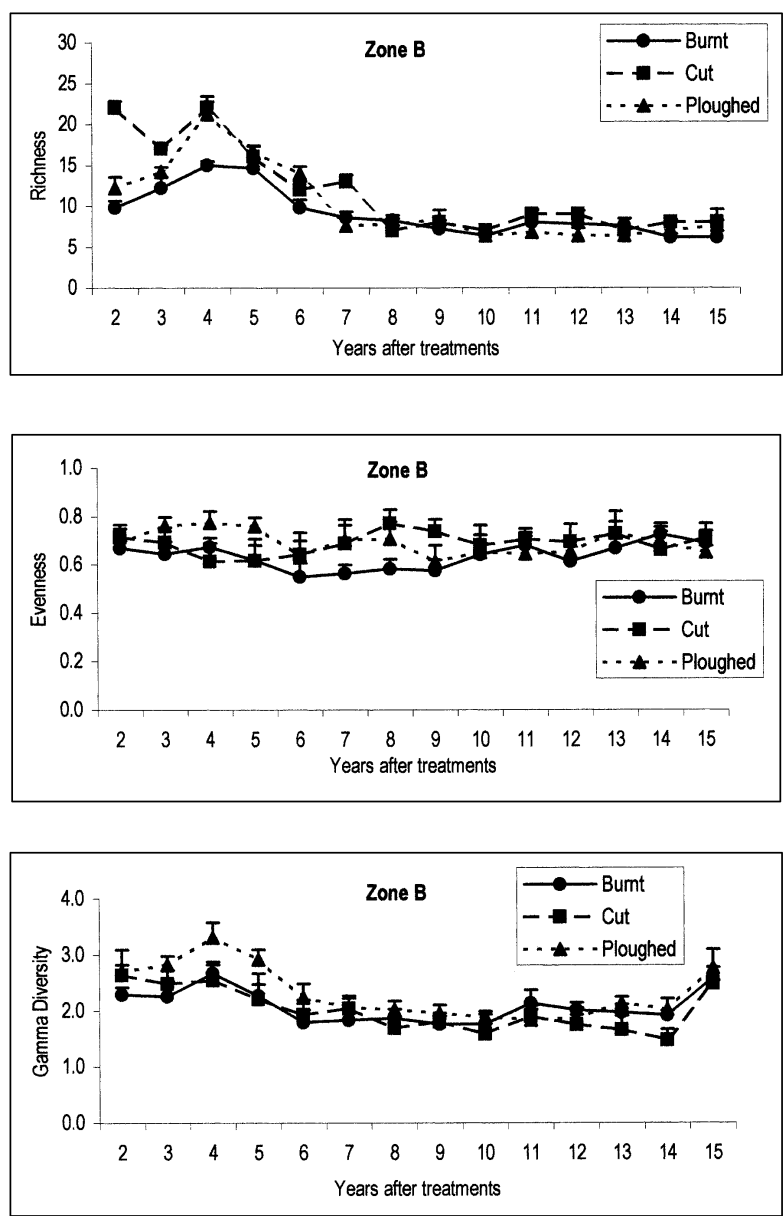

Fig. 7. Values through time for (a) species richness, (b) evenness and (c) gamma diversity after each treatment in zones A and B.

tribution The ploughed plot has the lowest values (Fig. 1). The same differences are present in zone B, but in this case, the highest values are recorded in the ploughed plot.

\subsection{Floristic diversity values}

The richness values are higher during the first few years after treatment and decrease over time (Fig. 7). This decrease is significant $(P=0.001)$ in zone $\mathrm{B}$, whilst differences are only appreciable after ploughing in zone A. Comparing the three treatments, differences in zone A between burning and ploughing are appreciable, since the latter has the lowest richness values. In zone B, differences can only be seen during the fourth year, since it has the maximum richness values for all three treatments, with cutting and ploughing greater than burning.

The evenness values (Fig. 7) show no significant differences $(P=0.0005)$ between treatments or over time within each treatment. In zone A, where the dominant species is Erica australis, the increase in its cover values in the last few years of the study slightly decreases the evenness values after burning and ploughing.

As regards gamma diversity, in zone A, significant differences $(P=0.005)$ can be observed between ploughing and burning or cutting, due to the decrease in cover after the sixth year following ploughing (Fig. 7). There are no differences between treatments in zone B.

\section{Discussion}

The regeneration response of these shrubs to cutting and burning is similar. Both treatments eliminate the aboveground biomass, keeping the sprouting organs and seeds viable in these zones. Both mechanisms stimulate regeneration (Trabaud, 1987; Ojeda et al., 1996). The main difference between the two treatments is that burning adds nutrients to the soil, mainly nitrogen (in general, these areas are nitrogen limited) (De Bano and Conrad, 1978; Kutiel and Kutiel, 1989; Marcos, 1997), which the species present can use. This contribution is used mainly by the perennial herbaceous species or hemicryptophytes, many of which keep their buds protected at ground level, including Tuberaria globularifolia, Hypochoeris radicata and Avenula marginata. In these resprouting species, the root system is always present and allows them to use water and nutrients quickly, whilst the seedlings from germination have to develop a completely new root system, which implies more 
time and greater sensitivity to environmental factors. Another perennial species, which stands out after burning in comparison with the other treatments, because of its high cover values, is the leguminous species Lotus corniculatus. Other authors in Mediterranean areas (ArianoutsouFaraggitaki and Margaris, 1982) have already stated the role played by leguminous species in post-fire plant recolonisation. Considering the low cover values in the original situation, this species probably came from a soil seed bank, as it is known that the seeds of leguminous species are very long-lived, allowing them to form large soil seed banks (Trabaud et al., 1997). The hardness and impermeability of the seeds of many woody genera are also well known. This makes their germination under normal conditions difficult (Casal, 1987). High cover values for this species may therefore be produced by factors associated with the fire stimulating germination (temperatures, exposure to light, reduction of toxins) (Martínez-Sánchez and Herranz, 1999).

Another difference between the two treatments is that the presence of open spaces after cutting favours the appearance of annual herbaceous species, particularly Aira caryophyllea. This has been noted by Willson (1992). In both cases, burning and cutting, the woody species that appear during the first few years are the typical resprouters of the zone, thus allowing this succession system to be compared to that described by Hanes (1971) as autosuccession. Immediately after perturbations such as burning and cutting, resprouter species, like Erica australis, mobilise stored carbohydrates and possibly also metabolised water in the roots. They are able to regain their former ground cover, dominant position and height after $4-5$ years. The same mechanism has been recorded by many other authors in succession studies on French garrigue (Trabaud and Lepart, 1980), shrub communities in Italy (De Lillis and Testi, 1990), phrygranic ecosystem studies (Arianoutsou-Faraggitaki, 1984), Portuguese Mediterranean maquis (Clemente et al., 1996) and also Israeli maquis (Naveh and Dann, 1974). In general, these resprouter chamaephytes, Erica australis and Chamaespartium tridentatum, can regenerate both from roots and by seed germination followed by vigorous growth.

Ploughing is the only treatment that can be compared to a classical secondary succession, with a sequence of changes defining different stages. This disturbance implies the obligatory use of germination as the recovery mechanism. Consequently, in the first stages, there is a clear dominance of herbaceous annuals, mainly Aira caryophyllea. From the third or fourth year, the woody species clearly dominate. Two Cistaceae, Halimium alyssoides and Halimium umbellatum, stand out due to their high cover values, mainly in the first few years. Both species are capable of using both sprouting and germination. According to the literature, germination is favoured when they are subjected to high temperatures (Thanos et al., 1992), as occurs with other Cistaceae genera (Valbuena et al., 1994; Trabaud, 2000). However, in this zone, we recorded maximum recovery values after ploughing, possibly due to the elimi- nation of competition with other woody species. The dominant species, Erica australis, has its highest germination values from the fourth year. The presence of herbaceous species with relatively high values during the first 5 years after ploughing may favour the germination of the seeds from woody species because of increased humidity in the upper centimetres of the soil (Brown et al., 1998).

In the three treatments, perennial herbs consistently maintain relatively small and nearly constant cover values over time. In general, herbaceous perennials were more abundant in the first 5 years after the treatments, although possibly less abundant than in other Mediterranean communities (Arianoutsou-Faraggitaki and Margaris, 1982; Arianoutsou-Faraggitaki, 1984; Carreira et al., 1992). However, the flush of herbaceous species (annual and perennial) after the three perturbations in these types of ecosystems is only temporary, and after 3-5 years, woody species form the dominant cover again. This coincides with the results obtained by Naveh (1999).

In the three treatments, the cover values for woody species increase significantly over time until years $7-8$, and then an asymptote is reached and the increases are less. Quercus pyrenaica, a phanerophyte species, which is the climax species in the two zones, is the main woody species. Its main regeneration mechanism is resprouting (Tárrega and Luis, 1990). However, it was not present in zone A in the original situation, so it has become established by germination in the cut plot after 15 years' study. These small oak seedlings appear to be protected under the largest Erica australis shrubs. The presence of woody species below shrubs has been described for many Mediterranean species (Zamora et al., 2001), where they benefit from the protection of shrubs against both herbivores and water stress.

At the entire plant community level, changes were most marked until the fourth to fifth year after all three treatments. This is due to the fact that it is a period when many herbaceous species, mainly annuals (therophytes), enter to take advantage of the lack of competition from woody taxa. Once the woody species reach high cover values, this competition displaces the annuals, with only some herbaceous perennials remaining for 15 years. The abundance of herbaceous perennials is inversely related to the amount of woody cover, i.e. where woody plants have less total cover, herbaceous species are of greater importance. This is due to competition for space and light. Competition for light is very important in multilayer communities similar to these (Vilá, 1997).

These marked changes in the cover values of the different life forms during the first few successional stages are reflected in the changes observed in the floristic diversity parameters, mainly richness and diversity. The highest values for the two parameters coincide with the maximum explosion of herbaceous species during the first 4-5 years, and then both decrease. This increase in the richness values in the first few stages has been described by other authors who analysed post-fire vegetation recovery (Naveh and 
Dann, 1974; Trabaud and Lepart, 1980, 1981; Casal et al., 1990; Bond and Van Wilgen, 1996; Cavero and Ederra, 1999; Naveh, 1999). The decrease in diversity values is produced by the community starting to stabilise or by the changes being brought to a standstill, and this results in a marked dominance of woody species and, in these zones, of Erica australis.

\section{Conclusions}

Shrubland communities dominated by Erica australis have a high resilience, responding rapidly to the disturbances produced by recurrent alterations since ancient times. After cutting and burning, there is a succession, defined by Hanes (1971) as autosuccession. After ploughing, there is a secondary succession in the classical sense, with a first stage of dominance by herbaceous species until the third year and a second stage of dominance by woody species from the fourth year. After the three disturbances, the increase in woody species is marked until the seventh to eighth year, and then the community stabilises. After burning, cutting and ploughing, the greatest changes at life-form level and structural level occur in the first 4-5 years, and from years seven to eight, the community stabilises. The introduction of the climax arboreal species Quercus pyrenaica, if it was not present in the original situation, is via seed germination. About 15 years are required for this to occur.

\section{References}

Arianoutsou-Faraggitaki, M., 1984. Post-fire successional recovery of a phrygranic (East Mediterranean) ecosystem. Acta Oecologica 5, 387-394.

Arianoutsou-Faraggitaki, M., Margaris, N.S., 1982. Phrygranic (East Mediterranean) ecosystem. Ecología Mediterránea 8, 473-480.

Barbero, M.G., Loisel, B.R., Quézel, P., 1990. Changes and disturbances of forest ecosystems caused by human activities in the western part of the Mediterranean basin. Vegetatio 87, 151-173.

Bond, W.J., Van Wilgen, B.W., 1996. Fire and Plants. Chapman \& Hall, London.

Brown, J.R., Scalan, J.C., McIvor, J.G., 1998. Competition by herbs as a limiting factor in shrub invasion in grassland: a test with different growth forms. Journal of Vegetation Science 9, 829-836.

Calvo, L., 1993. Regeneración vegetal en comunidades de Quercus pyrenaica Willd. después de incendios forestales. Análisis especial de comunidades de matorral. Doctoral Thesis. University of León, Spain.

Calvo, L., Tárrega, R., Luis, E., 1992. The effect of human factors (cutting, burning and uprooting) on experimental heathland plots. Pirineos 140, $15-27$.

Calvo, L., Tárrega, R., Luis, E., 1998a. Space-time distribution patterns of Erica australis L. subsp. aragonensis (Willk) after experimental burning, cutting, and ploughing. Plant Ecology 137, 1-12.

Calvo, L., Tárrega, R., Luis, E., 1998b. Twelve years of vegetation changes after fire in an Erica australis community. In: Trabaud, L. (Ed.), Fire Management and Landscape Ecology. International Association of Wildland Fire. Fairfield, Washington, pp. 123-136.
Carreira, J.A., Sanchez-Vasquez, F., Niell, F.X., 1992. Short-term and small scale patterns of post-fire regeneration in a semi-arid dolomitic basin of southern Spain. Acta Oecologica 13, 241-253.

Casal, M., 1985. Cambios en la vegetación del matorral tras incendio en Galicia. Estudios sobre Prevención y Efectos Ecológicos de los Incen dios Forestales. Ministerio de Agricultura, Pesca y Alimentación, Madrid, pp. 93-101.

Casal, M., 1987. Post-fire dynamics of shrublands dominated by Papilionaceae plants. Influence of fire on the stability of Mediterranean forest ecosystems. Ecología Mediterránea XIII (4), 87-98.

Casal, M., Basanta, M., González, F., Montero, R., Pereiras, J., Puentes, A., 1990. Post-fire dynamics in experimental plots of shrubland ecosystems in Galicia (NW Spain). In: Goldammer, J.G., Jenkins, M.J. (Eds.), Fire in Ecosystems Dynamics. SPB Academic Publishing, The Hague, pp. 3-42.

Cavero, R.Y., Ederra, A., 1999. Evolución de la composición florística post-fuego en un carrascal de Navarra (N de España). Pirineos, 153-154 61-100.

Cecconi, S., Polosello, A., 1962. Annali Sperimentazione agraría. In: Società Italiana della Scienza del suolo. Metodi Normalizzati di Analisi del Suolo. Edagricole, Bologna, p. 99.

Clement, B., Touffet, J., 1990. Plant strategies and secondary succession on Brittany heathlands after several fires. Journal of Vegetation Science 1, 195-202.

Clemente, A.S., Rego, F.C., Correia, O.A., 1996. Demographic patterns and productivity of post-fire regeneration in Portuguese Mediterranean maquis. International Journal of Wildland Fire 6, 5-12.

Cody, M.L., 1986. Diversity, rarity and conservation in Mediterraneanclimate regions. In: Soule, M.E. (Ed.), Conservation Biology: The Science of Scarcity and Diversity. Sinauer, Sunderland, MA, pp. 122-152.

De Bano, L.F., Conrad, C.E., 1978. The effect of fire on nutrients in a chaparral ecosystem. Ecology 59, 489-497.

De Lillis, M., Testi, A., 1990. Post-fire dynamics in a disturbed Mediterranean community in central Italy. In: Goldammer, J.G., Jenkins, M.J. (Eds.), Fire in Ecosystems Dynamics. SPB Academic Publishing, The Hague, pp. 53-62.

Di Castri, F., 1981. Mediterranean-type shrublands of the world. In: Di Castri, F., Goodall, D.W., Specht, R.L. (Eds.), Mediterranean-type Shrublands, Ecosystems of the World, vol. 11. Elsevier, Amsterdam, pp. 1-52.

Godron, M., Guillernm, J.L., Poissonet, J., Poissonet, P., Thiault, M., Trabaud, L., 1981. Dynamics and management of vegetation. In: Di Castri, F., Goodall, W., Specht, R.L. (Eds.), Mediterranean-type Shrublands, Ecosystems of the World, vol. 11. Elsevier, Amsterdam, pp. 317-345.

Grove, A.T., 1996. The historical context: before 1850. In: Brandt, C.J., Thornes, J. (Eds.), Mediterranean Desertification and Land Use. Wiley, Chichester, pp. 13-28.

Hanes, T.L., 1971. Succession after fire in the chaparral of southern California. Ecological Monographs 41, 27-52.

Junta de Castilla y León, 1987. Mapa de Suelos de Castilla y León. Junta de Castilla y León, Spain.

Keeley, J.E., 1986. Resilience of Mediterranean shrub communities to fire. In: Dell, B., Hopkins, A., Lamont, B.B. (Eds.), Resilience in Mediterranean Type Ecosystems. W. Junk, Dordrecht, pp. 95-112.

Kutiel, P., Kutiel, H., 1989. Effects of a wildfire on soil nutrients and vegetation in Aleppo pine forest on Mount Carmel. Israel. Pirineos 134, 59-74.

Le Houerou, H.N., 1993. Land degradation in Mediterranean Europe: can agroforestry be a part of the solution? A prospective review. Agroforestry Systems 21, 43-61.

Lloret, F., Vilá, M., 1997. Clearing of vegetation in Mediterranean garrigue: response after a wildfire. Forest Ecology and Management 93, $227-234$. 
Luis, E., Garzón, E., Tárrega, R., Zuazua, T., Calvo, L., 1989a. Proyecto I + D 10/84 agroenergética: comunidades de matorral, Options Méditerranéennes. Series Séminaires 3, 131-135.

Luis, E., Tárrega, R., Calvo, L., 1989b. Biomass and biomass regeneration after disturbance in shrub communities in León province (NW Spain). In: Grassi, G., Gosse, G., dos Santos, G. (Eds.), Biomass for Energy and Industry. Elsevier Applied Science, London and New York, pp. 1114-1120.

Marcos, E., 1997. Procesos edáficos en comunidades vegetales alteradas por el fuegos. Doctoral Thesis, University of León, Spain.

Margaris, N.S., Koutsidou, E., Giourga, Ch., 1996. Changes in traditional Mediterranean land-use systems. In: Brandt, C.J., Thornes, J. (Eds.), Mediterranean Desertification and Land-use. Wiley, Chichester, pp. 29-42.

Martínez-Sánchez, J.J, Herranz, J.M., 1999. Importancia de las leguminosas en las primeras etapas de la sucesión vegetal en un pinar quemado de la provincia de Albacete (España). Inves. Agr.: Sist Recur. For (Fuera de Serie 1), 273-282.

Ministerio de Agricultura, 1980. Caracterización Agroclimática de la Provincia de León. Dirección General de Producción Agraria. Subdirección General de la Producción Vegetal, Madrid, Spain.

Ministerio de Agricultura, 1984. Mapa de Cultivos y Aprovechamientos de la Provincia de León. Dirección General de Producción Agraria, Madrid, Spain.

Naveh, Z., 1999. The role of fire as an evolutionary and ecological factor on the landscapes and vegetation of Mt. Carmel. Journal of Mediterranean Ecology 1, 11-25.

Naveh, Z., Dann, J., 1974. Effects of fire in Mediterranean region. In: Kozlowski, T.T., Ahlgren, C.E. (Eds.), Fire and Ecosystems. Academic Press, New York, pp. 401-434.

Ojeda, F., Marañon, T., Arroyo, J., 1996. Postfire regeneration of a Mediterranean heathland in Southern Spain. International Journal of Wildland Fire 6 (4), 191-198.

Pielou, E.C., 1969. An Introduction to Mathematical Ecology. Wiley, New York.

Raunkaier, C., 1934. The Life Forms of Plants and Statistical Plant Geography. Oxford University Press (Clarendon), Oxford, pp. 632.

Rívas Martínez, S., Gandullo, J.M., Allué, J.L., Montero, J.L., González, J.L., 1987. Memoria del Mapa de Series de Vegetación de España. ICONA, Madrid, Spain.

Scheffe, H., 1959. The Analysis of Variance. Wiley, New York.

Shannon, C.E., Weaver, W., 1949. The Mathematical Theory of Communication. University of Illinois Press, Urbana, IL.

Tárrega, R., Luis, E., 1990. Forest fires and climatic features in León province (Spain)_fire effects on Quercus pyrenaica ecosystems. In:
Goldammer, J.G., Jenkins, M.J. (Eds.), Fire in Ecosystems Dynamics. SPB Academic Publishing, The Hague, pp. 63-69.

Thanos, C.A., Georghiou, K., Kadis, C.C., Pantazi, C., 1992. Cistaceae: a plant family with hard seeds. Israel Journal of Botany 41, 251-263.

Trabaud, L., 1980. Impact biologique et écologique des feux de végétation sur l'organisation, la structure et l'évolution de la végétation des garrigues du Bas-Languedoc. Thèse Doct. Etat Univ. Sci. Tech. Languedoc, Montpellier, France.

Trabaud, L., 1987. Dynamics after fire of sclerophyllous plant communities in the Mediterranean basin. Ecología Mediterránea XIII, 25-37.

Trabaud, L., 1991. Le feu est-il un factor de changement pour les systèmes écologiques du bassin méditerranéen? Sécheresse 3, 163-174.

Trabaud, L., 2000. Seeds: their soil bank and their role in post-fire recovery of ecosystems of the Mediterranean basin. In: Trabaud, L. (Ed.), Life and Environment in the Mediterranean. Wit Press, pp. 229-259.

Trabaud, L., Lepart, J., 1980. Diversity and stability in garrigue ecosystems after fire. Vegetatio 43, 49-57.

Trabaud, L., Lepart, J., 1981. Changes in floristic composition of a Quercus coccifera garrigue in relation to different fire regimes. Vegetatio 46, 105-116.

Trabaud, L., Martínez Sanchez, J.J., Ferrandis, P., González-Ochoa, A.I., Herranz, J.M., 1997. Végétation épigée et banque de semences du sol: leur contribution à la stabilité cyclique des pinèdes mixtes de Pinus halepensis et $P$. pinaster. Canadian Journal of Botany 75, 1012-1021.

Tutin, T.G., Heywood, V.H., Burges, N.A., Valentine, D.H., Moore, D.M., Walters, S.M, Webb, D.A., 1964-1980. Flora Europea. Cambridge University Press.

Valbuena, L., Tárrega, R., Luis, E., 1994. Influence of heat on seed germination of Cistus laurifolius and Cistus ladanifer. International Journal of Wildland Fire 2, 15-20.

Vilá, M., 1997. Effect of root competition and shading on resprouting dynamics of Erica multiflora L. Journal of Vegetation Science 8, 71-80.

Webb, N.R., 1998. The traditional management of European heathlands. Journal of Applied Ecology 35, 987-990.

Westman, W., O'Leary, J.F., 1986. Measures of resilience: the response of coastal sage scrub to fire. Vegetatio 65, 179-189.

Willson, M.F., 1992. The ecology of seed dispersal. In: Fenner, M. (Ed.), Seeds: The Ecology of Regeneration in Plant Communities. CAB International, Oxford, UK, pp. 61-85.

Zamora, R., Castro, J., Gómez, J.M., García, D., Hódar, J.A., Gómez, L., Baraza, E., 2001. El papel de los matorrales en la regeneración forestal. Quercus 187, 41-47. 